\title{
Study on environmental impact of pesticides application with agricultural sprayers in southern Adamawa state- Nigeria
}

\author{
${ }^{1}$ D.A Mada'2 A.I. Medugu \\ ${ }^{I}$ Department of Agricultural Engineering technology Adamawa state College of Agriculture, P.M.B 2088, \\ Ganye- Nigeria. \\ ${ }^{2}$ Department of agricultural Extension and management Adamawa state College of Agriculture, P.M.B 2088, \\ Ganye-Nigeria.
}

\begin{abstract}
Environmental impact of pesticides consists of the effects of pesticide on non- target species. Over 98 percent sprayed pesticide with agricultural sprayer reach a destination other than their target species because they are sprayed across agricultural fields. Rum off or wind drift can carry pesticide into aquatic environment, grazing areas, human settlement and undeveloped areas potential affecting other species. Over a time period repeated application increase resistance, while it affects the past resurgence. Each pesticide set of environmental concern, such undesirable effects have led much pesticide to be banned while regulations have limited and reduced the use of others in agricultural fields. However, the global spread, demand and dependence on pesticides as a management tool for crop protection had increased a detrimental effect on farm workers and stake holders. The result of the field studies in the study zone, estimated at least 164 cases of contracted diseases, 103 acute poisoned, 101 hospitalized and 28 untimely dead of farmers and farm workers. Available information raises in this study over $10-20 \%$ population of natural honey bee use for food were declined. Investigation carried out in the studies that 59 percent of sprayer operators, farm workers and stakeholder are not using personal protective equipment.
\end{abstract}

Keywords: - Environment, Effect, Pesticide, Agricultural sprayers, application

\section{INTRODUCTION}

The arrival of humans in an area to live or conduct agriculture necessarily has environmental impacts. These range from simple crowding out of wild plants in favor of more desirable cultivars to large scale impacts, such as reducing biodiversity by reducing food availability of native species, which propagate across food chain. The use of agricultural sprayers and pesticide had magnified the environment impacts. In which the beginning of eco toxicity in early 1960 had developed global public concern with result of acute poisoning event over the undesirable environmental effects of pesticides. The first pesticide commonly called DDT was originally used to combat malaria and its metabolites were shown to cause population level effect in bird and fish. Initial studies in industrialized countries have shown that there are acute mort ability effects mostly involving birds and fish. The proportion of publication has focused on effect related on animal, bird, fish, and aquatic life. Since 1993, the USA and European Union have updated pesticide risk assessments ending the use of acute toxicity of pesticide. One of the major challenges in this study is to link the result from other studies through levels of increasing complexity to environmental impact. The measureable effects of pesticide on Environment includes;-

(i) A research performed at Oak national laboratory (2000) showed condition of pesticide run off into Gulf of Mexico each year affect aquatic life and non agricultural activities.

(ii) World watch paper (December 2000) reported farmers in china experiencing toxic chemical contaminations of underground water emerging the world most valuable supply of fresh water.

(iii) A study published in the journal of Agricultural and food chemistry (May, 2000)

Showed DDT chlordane pesticide keep showing up in lettuce carrot,

and vegetables treated in a garden 38 years earlier.

(iv) A recent impact of pesticide at East brook and West middle school, Alana Quartuccio, reported on july 8, 2013, contain level of pesticide above the environmental standard. The sample showed elevated levels of aldrin, deldrin and chlordane all which was banned in the late 1980's, the school had been closed for month during remediation.

(v) Pesticide action network Europe (2010), reported in recent scientific literature on overall intensive pesticide application results in severe negative effect in the environment that cannot be ignored.

(vi) Rache Carson, (1962), an American courageous woman and scientist reported in her book the sudden dying of birds caused by indiscriminate spraying of pesticide. 
(vii) Analyzing U.S Department of Agricultural, pesticide data program comparing the relative amount and toxicity of pesticide residence in different foods a consumer union reported on February 1996, that fresh apples, grape, spinach and green beans had some of the highest toxicity index ratings

Agricultural sprayers are the most application machines and equipment it ranges in size and complexity form simple hand held models to intricate machines. Virginia polytechnic and state University (2013) reported on the limitation of agricultural sprayers, which include;

- Drift hazard of pesticide on operators and unintended areas.

- coverage may not be thorough

- High concentration present safety hazard.

- few pesticide are label for ULV

- use of concentrated pesticide may increased chance of dosage error,

However, the study will investigate the impacts of pesticide on environment and suggest alternative method of reducing the effects.

The study will focus on environmental Engineering which is the integration biological environment and Engineering principles to improve the natural environment. To provide healthy water, air and land for safety habitation for human, animal and other organism and to remediate pollution sites. Furthermore, it is concerned with finding plausible solution in the field of public health, implementing law which promotes adequate sanitation in urban and rural areas.

In many cases as societies grew, actions that were intended to achieve benefits for those societies had a long term impact which reduces other environmental qualities. One example is the widespread application of the pesticide 'DDT' to control agricultural pest in years following world war II,. While the agricultural benefits were outstanding and crop yield increased dramatically thus reducing world hunger. Malaria was controlled better than it ever had been applied on numerous species due to impact of DDT on their reproductive cycles. The story of DDT as vividly hold in Rachel Carson "silent spring" (1962) is considered to be the birth of modern environmental movement and the development of the modern field of environmental Engineering.

\section{MATERIALS AND METHODS}

The study was conducted between October and September 2013 In southern Adamawa state. The field survey was carried out in six (6) local government areas in Adamawa state, they comprise of Ganye, Demsa, Numan, Jada mayo belwa and Toungo..A total of 150 farmers were randomly selected for interview.The survey was conducted using the method of investigative survey,

Research Approach (ISRA) (Anozodo etal 1986). Information was collected using structured questionnaires. The questionnaires are close and open ended. In the close ended the farmers and the stakeholders have been given alternative choice of answer, while the open-ended allow them express their view freely. As shown in table I. Other source of information from oral interview, relevant journals and latest technical report from internet. Information conducted includes the followings; sales of pesticide, effect on environment, impact on farm workers and operators.

Table 1: Number of farmers responded and Samples size

\begin{tabular}{|l|l|l|l|l|}
\hline s/no & $\begin{array}{l}\text { Local government } \\
\text { areas }\end{array}$ & $\begin{array}{l}\text { No of questionnaires } \\
\text { distributed }\end{array}$ & $\begin{array}{l}\text { No of questionnaires } \\
\text { retrieved }\end{array}$ & $\begin{array}{l}\text { \% percent of } \\
\text { respodents }\end{array}$ \\
\hline 1 & Demsa & 15 & 13 & 10 \\
\hline 2 & Ganye & 50 & 50 & 343 \\
\hline 3 & Jada & 35 & 29 & 243 \\
\hline 4 & M/Belwa & 15 & 13 & 10 \\
\hline 5 & Numan & 15 & 19 & 10 \\
\hline 6 & Toungo & 18 & 12 & 12 \\
\hline 7 & TOTAL & 150 & 131 & 100 \\
\cline { 2 - 5 }
\end{tabular}

Source: Field survey (2013).

The tools for statistical analysis used for this study is descriptive statistic of the explanatory variables (both qualitative and quantitative)

III. RESULT AND DISCUSSION

Result obtained from field survey and quantitative analysis indicates severe impact of pesticide on Environment. The demand and sales of pesticide increase in the study as shown in Table 2 
Table 2: Sales use and dependence of pesticide in Ganye

\begin{tabular}{|l|l|l|l|}
\hline S/N & Sales Agent & $\begin{array}{l}\text { No of respondent } \\
\text { Farmers }\end{array}$ & Percentage of pesticide bought \\
\hline 1 & Open market & 110 & 84 \\
\hline 2 & Registered company & 4 & 2.5 \\
\hline 3 & Stock holder & 9 & 7.5 \\
\hline 4 & Government Agent & 8 & 6.0 \\
\hline & Total & 31 & 100 \\
\hline
\end{tabular}

Source: field survey 2013

Orhili (2010) reported that that there is rapid annual increase in sales, use and dependent on pesticide in developing countries.

Table 2, shows the highest percentage of pesticide sales from open market in which there is probability of using and depending on quacks and expired pesticide without original label from the manufacturer in the study zone. It may devalue manufacturerls standard and affect efficiency of pesticide in the market.

Table3: Period of exposure to pesticide in the study zone

\begin{tabular}{|l|l|l|l|}
\hline S/No & Period of exposure & No of contacted farmers & Percentage of responded farmers \\
\hline 1 & Above 5 years & 63 & 49 \\
\hline 2 & 6-10 years & 46 & 37 \\
\hline 3 & Above 10 years & 19 & 14 \\
\hline & Total & 128 & $100 \%$ \\
\hline
\end{tabular}

Source: Field survey 2013

Pesticide sales and usage in the study zone commence from 2000 to update. Exposure to pesticide shown in table 3 is 1 year to 5 years. duration of exposure range from mild irritation to birth defect, tumors, generic, blood and nerve disorder and even coma or death in human. Prolong exposure had led to contracted diseases, poison and untimely death as shown in table4

Table 4: Pesticide hazard on farm workers.

\begin{tabular}{|l|l|l|l|}
\hline S/N & Investigated Impact & No of affected farmers & Percentage of affected Farmers \\
\hline 1 & Contracted disease & 164 & 39 \\
\hline 2 & poison & 103 & 30.2 \\
\hline 3 & hospitalized & 101 & 30.0 \\
\hline 4 & Death & 28 & 0.8 \\
\hline & Total & 336 & $100 \%$ \\
\hline
\end{tabular}

Source: Field survey (2013)

Table 4, shows quantitative value of ill health and dead from field survey result in the study. Drift beyond intended spray areas is more likely harmful to farms workers.

Children are more susceptible and sensitive to pesticide because they are developing and have a weaker immune system than adult. They may be exposed due to their closer proximity to the store or potentially contaminated environment. However pesticide enters human through skin, mouth and breathing. .Skin contact is the common causes investigated in the study zone. This can be also occur through spillages or splashes on clothes of sprayer operators

Table 5: Pesticide impact on Environment in the study zone

\begin{tabular}{|l|l|l|l|l|}
\hline S/N & Group & Negative category \% & Total \% \\
\hline 1 & \multicolumn{1}{|c|}{ Negative effect } & No effect & \\
\cline { 2 - 5 } & $\begin{array}{l}\text { Source of fresh drinking water in } \\
\text { rural area }\end{array}$ & 83 & 17 & 100 \\
\hline 2 & Fish and aquatic life production & 80 & 20 & 100 \\
\hline 3 & $\begin{array}{l}\text { Bird species and honey been } \\
\text { production used for food }\end{array}$ & 78 & 22 & 100 \\
\hline 4 & Species of insect that pollinate crop & 94 & 6 & 100 \\
\hline
\end{tabular}


Source: Field survey (2013)

Table: 5shown 83 percentage negative trend of pesticide on source of fresh dirking water in the study zone. In U.S.A pesticide were found to pollute every stream. Over 90 percent of well sampled in a study by U.S Geological survey, 13th.september, 2007. Study by U.K government, 2007 had shown that pesticide concentration exceeded those allowable for drinking water in some samples of river water and ground water. Field studies in table 5 indicate 80 percent of fish and aquatic life production was negatively affected in study zone. Pesticide impacts on aquatic life are often studied using a hydrology transport model to study environment and fate of chemical in river and streams. The major investigated route through which pesticide reach water include: drift outside intended area, percolation, run off or leach through the soil.

In the study zone, $78 \%$ population of bird species had declined, while 15 to 20 percent 0 honey bees use for food had been decreased. The U.S fish and wild life service in June 2011, estimated that 72 million birds are killed by pesticide in the united state each years. Population of ten different bird species declined by ten million between $1979-1999$

A Study by Helfrich.L.A. al et, (June 1996) reported that fish and aquatic biota may be harm by pesticide through contaminated water. Pesticide can kill bees and, the loss of species that pollinated plants. The USDA estimated that U.S farmers loss at least \$200 million a years from reduced crops pollination. The honey bees use for food had been decreased by 15-20 percent in the study zone.

Table.6: Pesticide impact on crop protection machinery operators

\begin{tabular}{|l|l|l|l|}
\hline s/n & Status of operators & No of contacted farmers & Percentage of respondent \\
\hline 1 & Professional operators & 16 & 12 \\
\hline 2 & Trained operators & 65 & 50 \\
\hline 3 & not trained o0perators & 44 & 38 \\
\hline
\end{tabular}

Source: field survey 2013

Table 6 shows the impact of pesticide on machine or equipment operators, in which $38 \%$ percent of operators are trained in the study zone. Operators come directly to inhale fume or dust, gas, vapor or spray mix beyond the intended sprays area.

Fumigation with equipment had been linked to lose other agricultural resources in the study zone. Sudden death of fish, bird as well as starvation of animal grazing on sprayed field.

Field study reported by environmental protection Agency (EPA) that 10,000-20,000 related incident each year..Out of 27 most common pesticide identified by U..S environmental Agency,15 are considered with additional link to nervous disorder and respiratory condition .

\section{CONCLUSION}

This study summaries information on the behavior of pesticides and their impact on environment, an extensive field survey in southern Adamawa State Nigeria.

Pesticide applied on environment at recommended level rarely had a detrimental effect on human, animals, fish, bird and aquatic and their activities. Data ware quantified, tabulated and negative trend were analyzed with correct knowledge of pesticide management. There is concern on pesticide impact investigated in the field survey, which may cause;

(i) Environmental hazard to human, animal and aquatic life.

(ii) Biological in balance in human, animals, birds and fish.

(iii) Reduce of efficiency because of shift toward soil micro organism and more efficient in pesticide and the degradation in the study zone.

The field study estimated that at least 164 cases of contracted diseases, 103 acute poison, 101 hospitalized farmers and 28 untimely deaths. Available information from the study over $10-20$ percent production of natural source of honey bees used for food was declined owing to continue exposure to pesticide.

Another information from the study zone carried that $59 \%$ of sprayer operators have not adapted personal protective equipment (PPE), which include gloves, aprons, respirator, footwear, eyes wear, headgear and protective suit.

The alternatives to reduce effect of pesticide in the study include;

(i)Farmers to employ a buffer zone around their crops, the buffer zone consist of empty land or non-crop-plant such as evergreen trees. It serves as wind break, observes and prevents pesticide drift in to other area as adopted in Netherland.

(ii)Farmers and stake holders should be encouraged to use personal protective equipment (PPE) While handling pesticides. 
(iii)Sprayer operators should avoid washing of sprayers, empty tanks and protective suits in stream, river and near source of shrinking water to reduce contamination in the zone.

\section{REFERENCE}

[1] Kellogy R.L Nehring R. Grube, A .Goss .O.W. and plo kin ,S. Environmental indication of pesticide leaching and run off fields U.S.A. department of agriculture natural resources conservation service [2007]

[2] Reynolds J. D. International pesticide is there any hope for the effective regulation of controlled substance, Florida state university journal of land use and environmental law [1997] vol 131 reviewed on 2007-10-16

[3] Bingham, S. Pesticide in rivers and ground water Environment agency UK [2007] state of Jersey Environmental protection and pesticide use [2002]

[4] FOX, E. Gulledge, I. Engehaught, B. Burrow , M.E. Mcclachla , I.A. Pesticide reduce symbiotic efficiency of nitrogen fixing rhizobia and host plant .Proceeding of national academic of science of USA 184 [24]10282-10287

[5] Orhil, P. Sensitization workshop on safe and responsible use of agro chemical $8^{\text {th }}$ Feb.2010, Yola .pp 1-6 Soil sample shows pesticide at West book middle school ground, July 8-2013 at 07.20 pm posted by Alana quartuccio [editor ]

[6] Roget A .I. SImpson B.R. Official ,S.Ardalles,C. Jimene, ,C. Effect of pesticide on soil and water micro flora and mesoblora and mesofanna in net land rice fold a summary of current knowledge and extrapolation to temperate environments. Universite de province Hugo 13331, France .Australians journal of experimental agriculture [1984]

[7] Mada D.A.,Duniya ,N. Idris,A.G. Effect of continuous application of pesticide on soil and environment in southern Adamawa state .International Referred journal of Engineering and Science [IRJES] June 2013 .issue vol 2. pp. 52

[8] limy, R.P. and Wong, M.G. The effect of pesticide in the population dynamics and production of sterocrypris, major bird in rice field [i986] achieve for hydrobiology 106, 44-7

[9] Oka, I.N. Future needs for pesticide management in south east Asia in 1981 consortium for international protection, USA

[10] Mathews, G.A. Pesticide application methods. Third Edition black well science [2000] 432 pages oxford.

[11] Sprayers and other Application Equipment ,Drop data. Org. retrieved 2009-04-10

[12] Beeker ,kurt [June 2008] ' Fogging for effective pest management G P N magazine [G P N magazine] 44 $-45 /$ retrieved 18/03/2013

[13] Van Neikerk ,J.M.. Z.S. Mavus [2012] Evaluation of utra-low volume funagicide application for the control of diseases owocado fruit south African avocadofruit South African Avocado growers association year book retrieved 18/03/2013

[14] Hodgson, ernest, levi, patricia, E pesticide; An important but under used for the environmental health sciences, perspective supplements, mar 1996/vol 104.Academic search engine

[15] Riher .I. Solomon,K.R. and Forge.J.Stenerolf, M. and Oiler, C.'Persistant organic pollutants ‘ An assessment report on DDt, AIdrin, dieltrin endrn, chlordance. Intsination programe on chemical safety [IPCS].

[16] Daniel, Julie I. Andrews, F. David ,A. sans, Z. Pesticide and children concern department of epidemimiology school public health, university Carolina, chapel William 105 October 1997.

[17] Mada D. A. Ma hai, S. Adamu, I.G. Gerei, M.M. [2014]. Toxicity study of pesticide on storage of cereal, legumes and oil seed with regard to storage structure in Ganye southern Adamawa state Nigeria International journal of engineering research and development Vol 10 issue 3 [march 2014] PP33-39

[18] Mada,D.A , Hussaini,I.D.Investigation in the Effect of pesticide application on soil and Environment with crop protection machine in southern Adamawa state Nigeria Internal journal of Engineering and Science [The IJES] vol 12 issue 12 PP 71-76 2013

[19] Anasco N. Uno,S. Koyama,J.Matsuoka, Z..Kuwahara,N. [2010 ]Assessment of pesticide residues in fresh water areas affected by rice paddy effluent in southern Japan , Environmental monitoring and assessment 160 I D P P371-383

[20] Anas Esteyez, M. lopez -reriago E. Martinez Carballo, E. Simal, Gandea, J. Mejuto, J. C Garcia -rio L. [2008] The mobility and degradation of pesticide in soils and the pollution of ground water resources ,Agriculture ecosystems and environment 123 [4] P247-260

[21] Barrac bugh, D. keamey, T. Croxford, A [2005]. Bound residue environmental solution or future prolem environmental pollution $133 \mathrm{D}$, PP 85 -90

[22] Bocquene, G, Franco, A. [2006] Pesticide contamination of the coastline of martinque marrin pollution bulletin 51 [5-7] pp 619 
[23] Britain C,A Vighi, M. Bommarco, R. Stele, J. Pots, S.G. [2010] Impacts of pesticide on pollinator species richness at different spartial scale .basic and applied ecology 11 [2] pp 106 -115

[24] Bright, J.A.morris A.J. winspear, R. [2008] A review of indirect effect of pesticide on bird and mitigating land -management practice research report 28, royal society for the protection bird

[25] French,1. Balog,A.(2010). A pesticide survey in soil water and foodstuffs from entral Ramania,Carpathain journal of Earth and Enviromental sciences April 2010 5(1) pp111-118

[26] Liebich,J. Schaffer,A. Buravel ,P.(2003) Structural and Functinal approach to studying pesticide sideeffects on specific soil function.Journal of Environmental Toxicity and chemistry 22(4) 784-780

[27] Navarro,G. Vela,N. Navarro,S.(2007) Review An overview on the Enviromental behavior of pesticide residues in soils.Spanish Journal of Agricultural Research 5 (2) pp357-375

[28] Relyea ,R. A.(2005a). The impact of insecticides and herbicide on biodiversity and production of aquatic communities ecological application 15 (2)pp 618-627

[29] Relyea ,R. A. Hoverman,J.T. (2008). Intractive effects of predators and a pesticide on aquatic communities oikos 117(11) pp1647-1658

[30] Russusell, c. Schltz, C.B.(2009). Effects of specific herbicides on butterflies and experimental investigation to advance conservation effort. Journal of of insect conservation 14 (1) pp53-83

[31] White, P.J. Kerr,J.T.(2007). Human impact on environment-diversity relationships envidence for biotic homogenization from butterfly species riches pattern Global Ecology and Biogeography 16(\#)pp940-947

Figure1: Sales, use and dependence on pesticide

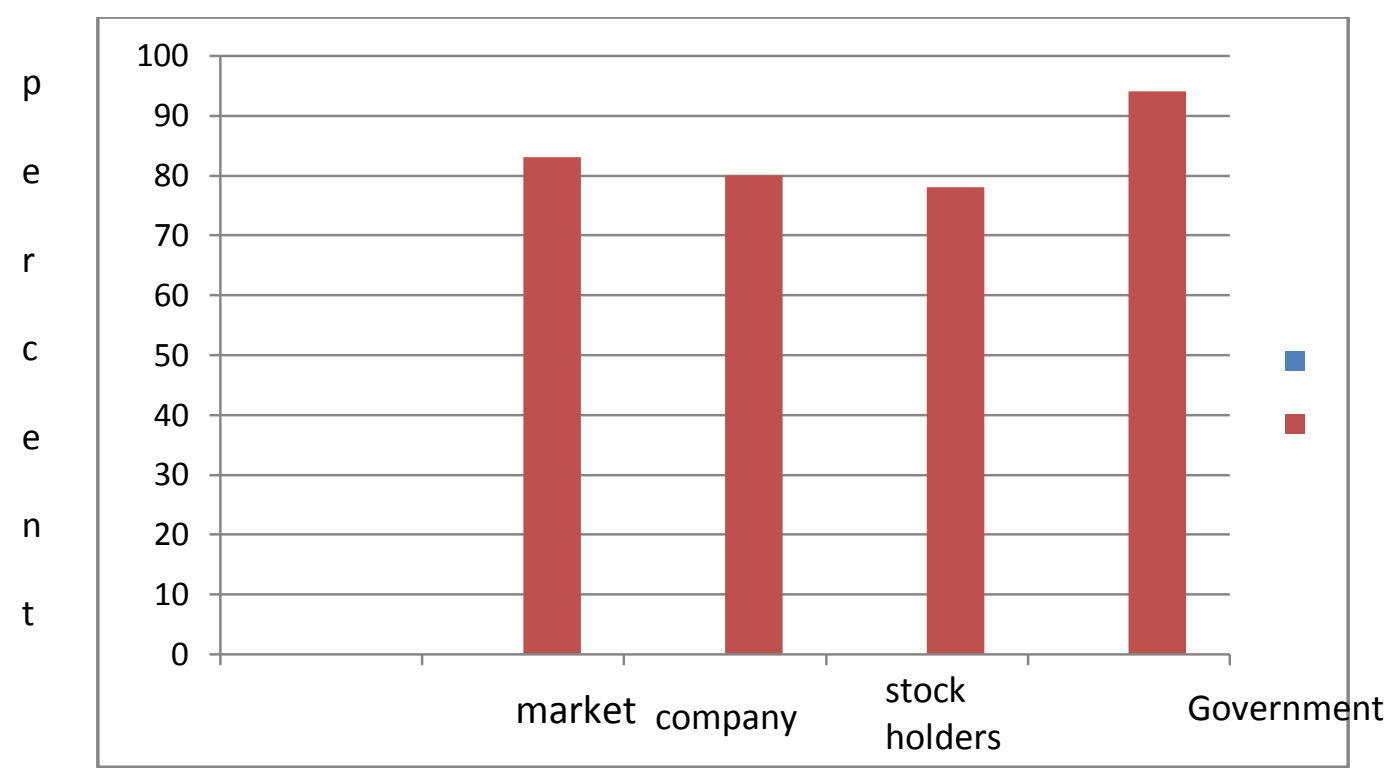

Source: Field survey, 2013 
Figure2: Pesticide hazard on farm workers

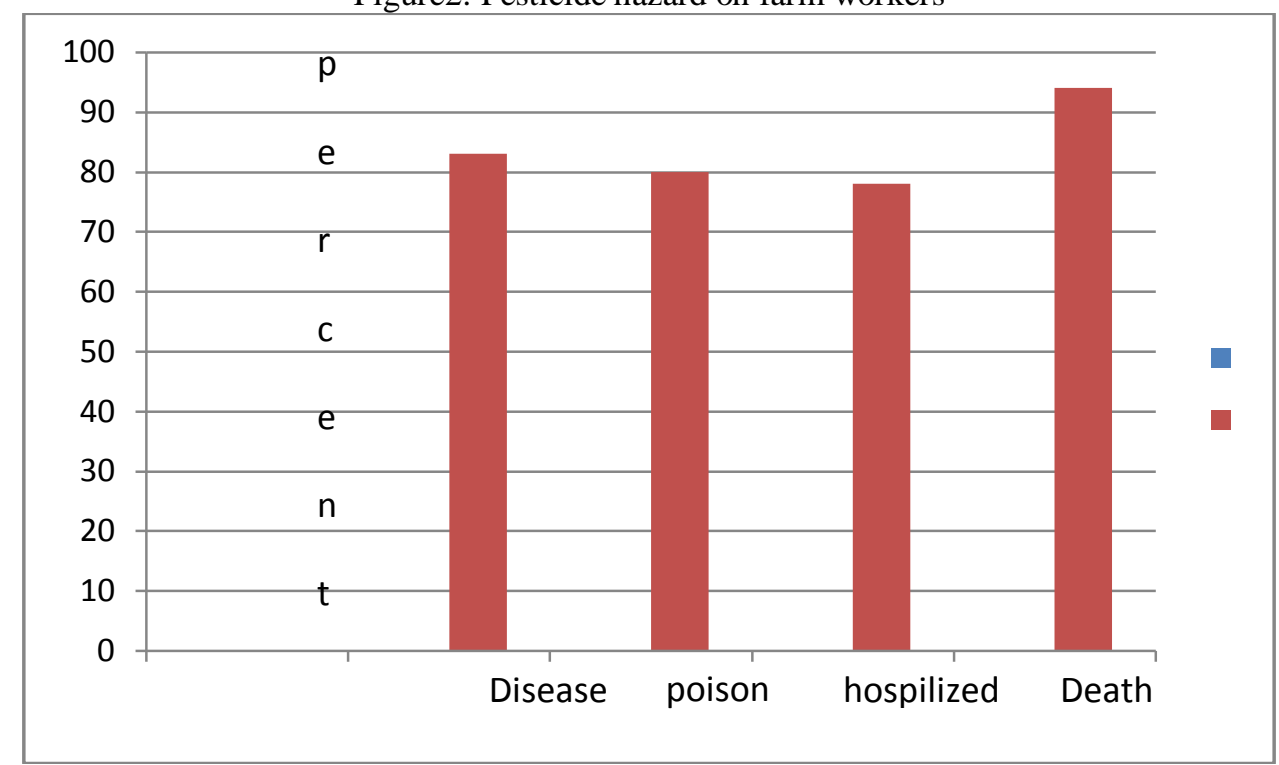

Source: Field survey, 2013 